
Digitized by the Internet Archive in 2011 with funding from University of Toronto 






\section{CONTRIBUTIONS OF THE}

\section{ROYAL ONTARIO MUSEUM OF PALAEONTOLOGY}

N0.4: DEVONIAN BRYOZOA FROM FORTIN AND MALBAY TOWNSHIPS, GASPE COUNTY, QUEBEC

BY Madeleine A. Fritz 


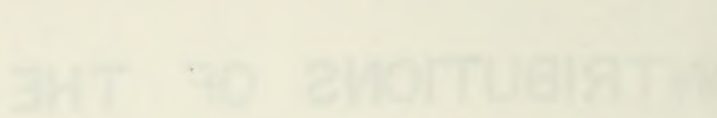

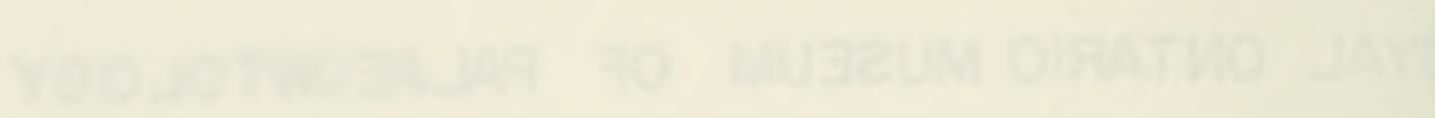

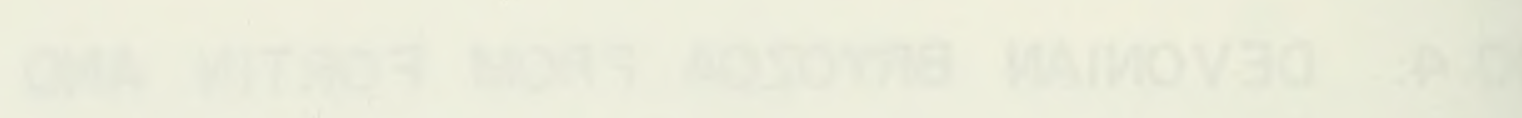

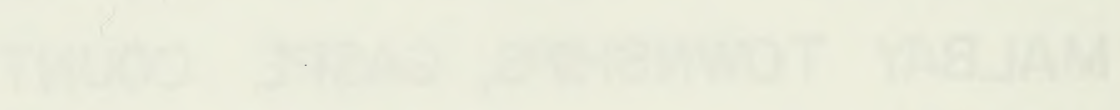

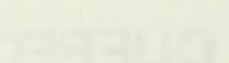

-

$x^{2}+x^{2}-2$ 
Published by authority of the Board of Trustees Royal Ontario linseum

Torontc, Canada

Price, 15 cents 

DEVONIAN BRYOZOA FROM FORTIN AND MAIBAY TOWNSHIPS

GASPE COUNTY, QUEBEC

By Madeleine A. Fritz

Assistant Director of Invertebrate Palaeontology

\section{INTRODUCTION}

The bryozoan faunas of Gaspé have recelved very little attention in the past. Aside from a few brief references to these organisms by $\mathrm{Clarke}^{\mathrm{l}}$ and a recent paper by the writer ${ }^{2}$ no attempt has been made to consider these stratigraphically important fossils.

Fortunately the quebec Bureau of Mines in their recent surveys in Gaspé are making an effort to include in their fossil collections examples from all the bryozoa-bearing strata met pith in the course of their work. From the material which is being thus assembled there is ample evidence of a prolific bryozoan fauna although the preservation of the various forms represented is, on the whole, not good. The rocks, which consist chiefly of sandstones and crystalline limestones, are so hard that in many instances it is practically impossible to remove the specimens from their matrix or to make them avallable for study. Furthermore, the sandstone species are represented for the most part only by casts and molds. This condition of preservation leads to considerable uncertainty with regard to the determination of specific characteristics. In spite of these difficulties, however, a distinctive fauna is being gradually recognized.

\section{PRESENT INVESTIGATION}

The material which forms the subject of this paper was collected by Dr. H.W. McGerrigle of the Bureau of Mines, Quebec. It was obtained from Fortin and Malbay townships which are located towards the southeastern part of Gaspé county, at the eastern end of Gaspé 

peninsula. Fossil localities represented include:

F7-M-39 Fortin Tp.; Range II; near head of small brook one mile west of the Fortin-Nialbay line.

F9-11-39 Fortin Tp.; Range III; debris on top oI divide between Malbay river and the Bif Fork of the Malbay river; one-third mile east of Fortin Centre line.

F13-Ni-39 Fortin Tp.; Range VIII; close to R. VIIVIII line; about two miles west of Fortin-Malbay line.

Fll-M-39 Fortin Tp.; Range VII, close to R. VITVIII line, about one mile and a quarter west of Fortin-Malbay line.

F21B-M-39 Malbay Tp.; Range IV south; on Otter (Pass) creek one-half mile north of Portage river.

F25-M-39 Malbay Tp.; Range IV, 1,000 feet west of Range III-IV line on Portage river.

From the small collection obtained at the se localities the following specles have been recognized:

Anastomopona quebecensis Fritz 1938

Anastomopora sp. indet

Fonestrellina fortinensis n. sp.

Fonestrellina gaspiensis Fritz 1938

Fistuliphragma jonesi n. sp.

Fistulipora sp. indet

Lioclema magerriglei n. sp.

\section{DISCUSSION OF FAUNA}

of these above mentioned species Anostomopora guebecensis and Fenestrellina gaspiensis are known only Irom the Gespe peninsula. The former ${ }^{3}$ was described originally from Four Mile creek, near Causapscal, Quebec, in the Matapedia valley of western Gaspe; the latter 4 from the east branch of Sonneau brook, Gali township, on the north side of York river valley in eastern Gaspe:. The strate from both of these locali- 

ties are considored to be of Gaspe sandstone age 5 . The finding of these two species in association in the Fortin-Malbay district assists in establishing relationships between Gaspe sandstone strata in several areas throughout the peninsula.

An undetermined species of Anastomopora occurs at locality F2l-M-39. It is represented only by a single cast which does not warrant definite specific determination. It bears a marked resemblance to the Gaspé sandstone species $A$. quebecensis but the horizon at which it occurs is, according to vicGerrigle, approximately one thousand reet (stratigraphically) down in the Grande Greve limestone from the Gaspe sandstone contact. The striking similarity between the form in question and $A$. quebecensis might provide evidence to substantiate the belief that the Grande Greve limestone and overlying Gaspé sandstone are closer in age than is generally admitted.

Two other species Fenestrellina fortinensis and Fistuliphragma jonesi represent new specles from the Gronde Grève limestone. Descriptions of these species appear later in this paper. Fenestrellina fortinensis is abundant and well preserved at localities F13-iil-39 and F11-M-39. At the former locality it represents a good horizon marker. Fistuliphragma jonesi is of rare occurrence at iocality Fll-M-39. It is of particular significance in this fauna in that the genus Fistuliphragma, which is typically developed in the Hamilton formation of Michigan, has not been reported hitherto from a point in North America as far east as Gaspé. Occurring in association with Fistuliphragma jonesi is an undetermined species of Fistulipora. Though fragmentary remains of this species are not uncommon the state of preservation permits only a generic reference. The age of the remaining species Lioclema mcgerri$g l e i$, herein described from locality F25-M-39, is attended with some difficulty. The Devonian representatives of this genus are characteristic of the Belderberg and Hamilton formations. Since the strata in which this species is found are definitely not Hamilton I would incline to the belief that a Lower Devon1an horlzon below the Grande Greve is here represented. 



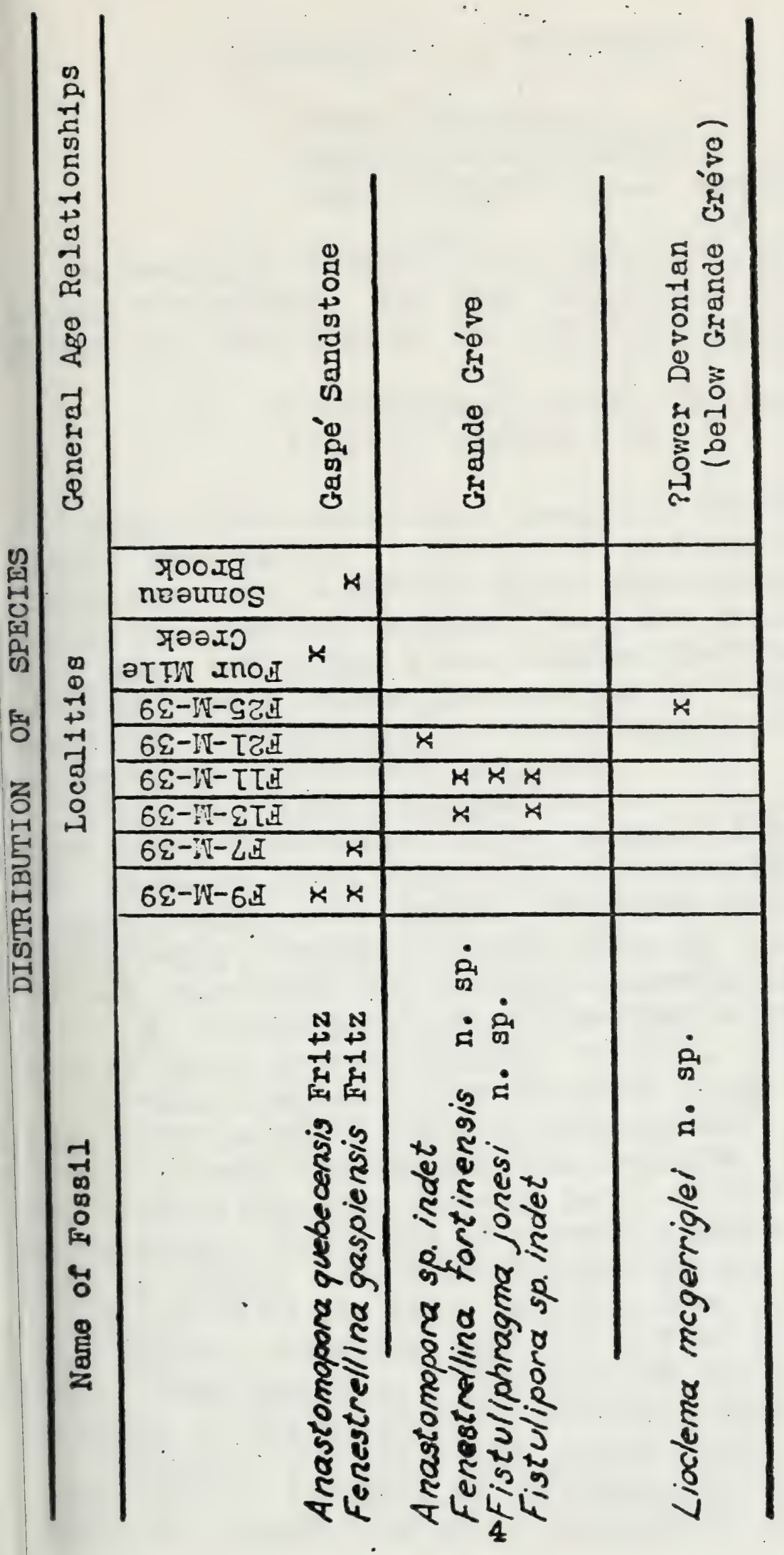

194

म 13

in 4

or $p_{1} 0$

क م

$\sum_{1}$

के 농

अ च ज

$\rightarrow$ \& 0

구

ฟ

0 웅

$\leftrightarrow$ म

\& $N$

मै भु मु

엉 여

ฮี

$+$

o) 0

म म.न

(1) त्-

맏

उ 09

$\mapsto 0+$

भ ब

(1) $0_{1}-1$

की $\mathrm{H}$

H 4 \&

\&

एै 00

- $\frac{9}{1} \frac{1}{3}$

붕

\& $m$ ह

410

문

당

+ 0

c) क से

대 요

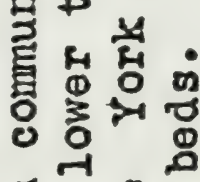

$4-10$

A $>\frac{1}{4} 5$

Hन 

Order Cyclostomata

Family Fistuliporidae

Genus Fistuliphragma Bassier

According to Bassler ${ }^{8}$ this genus differs from the tyoical Fistulipora in that hemiphragms or semidiaphragms are developed in the zooeclal tubes.

Fistuliphragma jonesi n. sp.

Plate I, Figures 2,3,4,7.

General Features.--This species is founded upon a single fragment of a zoarium which forms a thin incrustation over a portion of crinoid column. In its length the specimen measures $7 \mathrm{~mm}$. The observed thickness does not exceed $1 \mathrm{~mm}$. Surface features are not distinguishable since the specimen is longitudinally fractured through the centre and reveals only a natural vertical section of the tubes.

Tangential Section.--The zooecia are small elongate-ovate structures. On an average four appear in the space of $1 \mathrm{~mm}$. They are separated by vesicular tissue which about equals the width of a zooecium. occasionally, however, broader areas of vesicular tissue are seen which may constitute inconspicuous maculae. A fairly well-marked lunarlum is present, the ends of which project into the zooecla.

Vertical Section.-The zooecia curve gradually from their point of origin to the surface. Fron 2 to 8 rows of well rounded vesicles separate the zocecial tubes which are, for the most part, filled with clay. Hemiphragms are present in certain zooecia and are absent in others. Their absence may be due to poor preservation or to the fact that they were not developed. When present there are from two to four in each zooeclum. They appear on either side of the tubes and are situated at distances apart of over a tube diameter.

Remarks.-- Fistuliphragma jonesi differs from the other species included in this genus in its incrusting habit of growth and small dimensions. The genotype 

F. spinulifera (Rominger) is a stout, monticulose, branching form while $F$. saffordi (inchell) is largor than the present form and grows in lamellate layers.

Holotype.--Number 20:374, Rojal Ontario Eusarum of. Palae ontology.

Occurrence.--Rare in Grande Gròve limestone, locality Fll-Mi-39.

Order Trepostomata.

Family Batostomeilidae

Genus Lioclema Ulrich

Lioclema mcgerriglei n. sp. Plate I, Figures 6,9.

General Features.--The zoarium is ramose. Only a single branch is present in the collection. It is round in cross section the diameter measuring $4 \mathrm{~mm}$. The length of the branch is approximately $30 \mathrm{~mm}$. The surface is not well preserved but would appear to be smooth.

Tangential Section.--The zooecia are round to oval in outline. They are separated by numerous, rather thick-wailed mesopores of varying sizes. An average of three zooecia appear in the space of one millimetre measuring longitudinally. Acanthopores occur but they are not. conspicuous and they do not tend to greatly inflect the walls. Their presence is indicated merely by a few fairiy large mural granules. Certain of the mesopores appear to be closed at the surface which fact probably accounts for their varying sizes.

Vertical Section.--The zcnecia curve gradually from the axial to the peripheral region. The walls, which are thin, maintain a uniform thickness throughout their entire length. In the peripheral region an occasional diaphragm may be detected in the zooecia. The numerous mesopores, however, contain diaphragms in abundance, which gives to these structures the appearance of regular vesicular tissue.

Remarks.--The available material does not show very clear relationships between this form and any other previously described species of Lioclema. It 

has been thought desirabie, however, to record the above features with the hope that further material will be found that may permit a closer comparison with the known species.

Holotype.-Number 20375, Royal Ontario liuseum of Palaeontology.

Occurrence.--Rare in Lower Devonian(?), locality F25-ki-39.

Order Cryptostomata

Family Fenestrellinidae

Genus Fenestrellina Bassier

Fenestrellina fortinensis n. sp.

Plate I, Figures $1,5,8$.

General Features.-The form of the zoarium suggests a flabellate expansion but since identification has been made from fragments only the exact size of the colony is not known. The largest specimen observed measures $30 \mathrm{~mm}$. by $20 \mathrm{~mm}$.

Obverse.--Unfortunately only the reverse side is exposed on the various specimens representing this species. The following characters of the obverse side have been determined, however, by means of thin sections. The zooecia are round. They are arranged, as a rule, in two rows though three rows may occur prior to the bifurcation of a branch. A somewhat zigzag median keel separates the rows. Three to four zooecia occur in the length of a fenestrule which they tend to slightly inflect. The dissepiments are stout structures. Three commonly appear in the space of $3 \mathrm{~mm}$. measuring longitudinally. They are broadest at the point of junction with a branch.

Reverse.--In the mature portion of the colony the branches show a parallel arrangement. They are round and fairly stout measuring $0.7 \mathrm{~mm}$. in width an average of six or seven apnearing in the space of $5 \mathrm{~mm}$. The fenestrules are round to oval in the immature part of the zoarium. They tend to elongate, however, as colonial growth continues. Reaching maturity they become -quite irregular in size and shape ranging fror a width 

of from 0.5 to $0.75 \mathrm{~mm}$. to a length of from $0.75 \mathrm{~mm}$. to over $1.5 \mathrm{~mm}$.

One of the most striking features of the reverse side is the presence on the branches of nurerous fine, well-marked, irregularly disposed tubercies of varying sizes. These markings give to the surface of the branch a distinctly grenular appearance. The dissep1ments, which are strongly developed structures, are similarly ornamented.

Remarks.--F. fortinensis is the most characteristic species at locality F13-M-39 where it is abundant. It occurs, also, at locality Fll-M-39. This form may be distinguished from all the other Gaspe species thus far studied by the finely tuberculated reverse surface. This feature is not unique among the fenestrellinids but the specles in which this particular characteristic has been observed differ from the present form in other essential details.

Cotypes.-Number 20373, Royal Ontario Museum of Palae ontology.

Occurrence.-Grande Gréve Iimestone. Common at. locality F13-1:39.

\section{SURMARY}

From the foregoing study of a small collection of bryozoa obtained by H.W. NeGerrigle of the Quebec Bureau of Mines from Fortin and Malbay townships in Gaspe county, in the southeastern part of Gaspe peninsula, three new species Fistuliphragma jonesi, Lioclema mogerriglei, and Fenestrellina fortinensis have been described. In addition, the investigation has provided evidence which may assist in correlating Gaspe sandstone strata in several areas throughout the peninsula. 

1. Clarke, J.M., 1908; N.Y.S.M., liem. 9, pt. I, pp. 215-242.

2. Fritz, N.A., 1938; Bulls. Amer. Pal., vol. 24, App. $82 \AA$, pp. 1-14.

3. Fritz, M.A., 1938; Bulls. Amer. Pal., vol. 24, App. $82 \mathrm{~A}, \mathrm{p} .5, \mathrm{pl}$. I, fig. 5 .

4. Fritz, M.A., 1938; Bulls. Aner. Pal., vol. 24, App. 82A, p. 7, pl. I, figs. 1,3,4.

5. Kindle, E.M., 1938;Bulls. Amer. Pal., vol. 24, p.4l. 6. Jones, I.N., 1937; York River Area; Quebec Bureau of Mines, p. 22.

7. Kindle, E.M., 1938;Bulls. Amer. Pal., vol. 24, p.44.

8. Bassler, R.S., 1934; Jour. Wash. Acad. Sci., vol. 24 , no. 9, p. 407. 



\section{EXPILANATION OF PJATES}

Fig. 1. Fenestrellina fortinensis n. sp. Tangential section, celluliferous side; X35.

Fig. 2. Fistuliphragma jonesi n. sp. Tangentiai section showing maculur and zooecia with Iunaria; X.35.

Fig. 3. Fistuliphragma jonesi n. sp. Vertical section showing hemiphragms and vesicular tissue; X25.

Fig. 4. Fistuliphragma jonesi n. sp. Veriteai section showing hemiohragms and vesicular tissue; X25.

Fig. 5. Fenestrellina fortinensis n. sp. Tangential section, non-celluliferous side showing granules; X35.

Fig. 6. Lioclema magerriglel n. sp. Vertical section showing a zooecium with few diaphragns also mesopores with numerous irregular diaphragns; X35.

Fig. 7. Fistuliphragma jonesi n. sp. Vertical section; $X 35$.

F1g. 8. Fenestrellina fortinensis n. sp. Fragment of zoarium, non-celluliferous side; 25 .

Fig. 9. Lioclema mcgerriglei n. sp. Tangential section showing zooecia,irregular mesopores, and acanthopores; 235. 


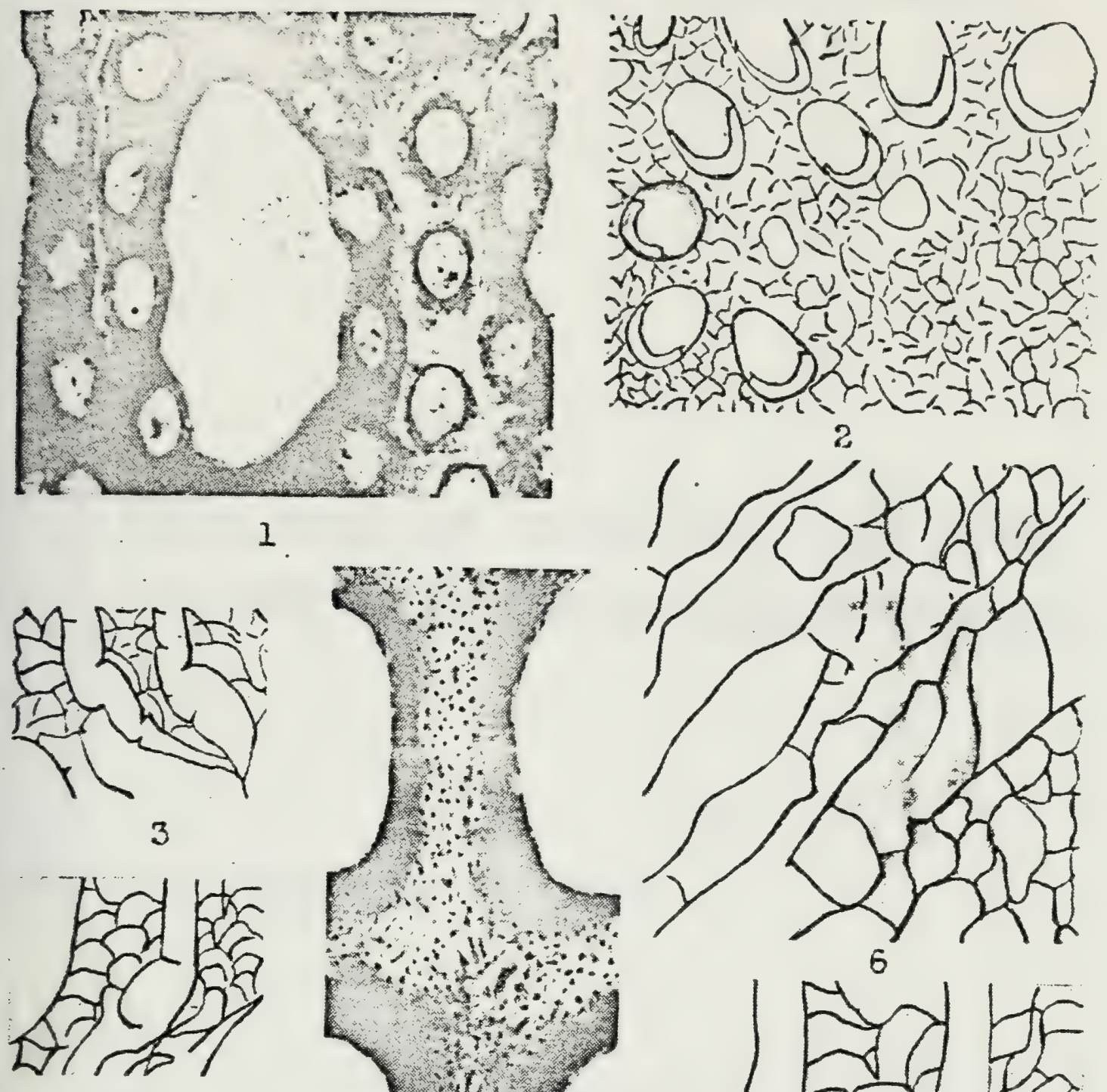

4

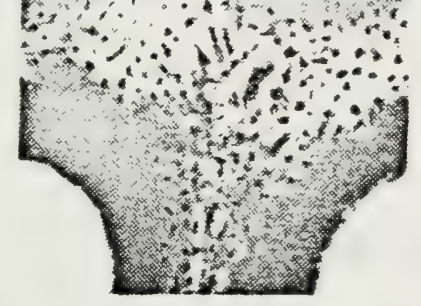

5
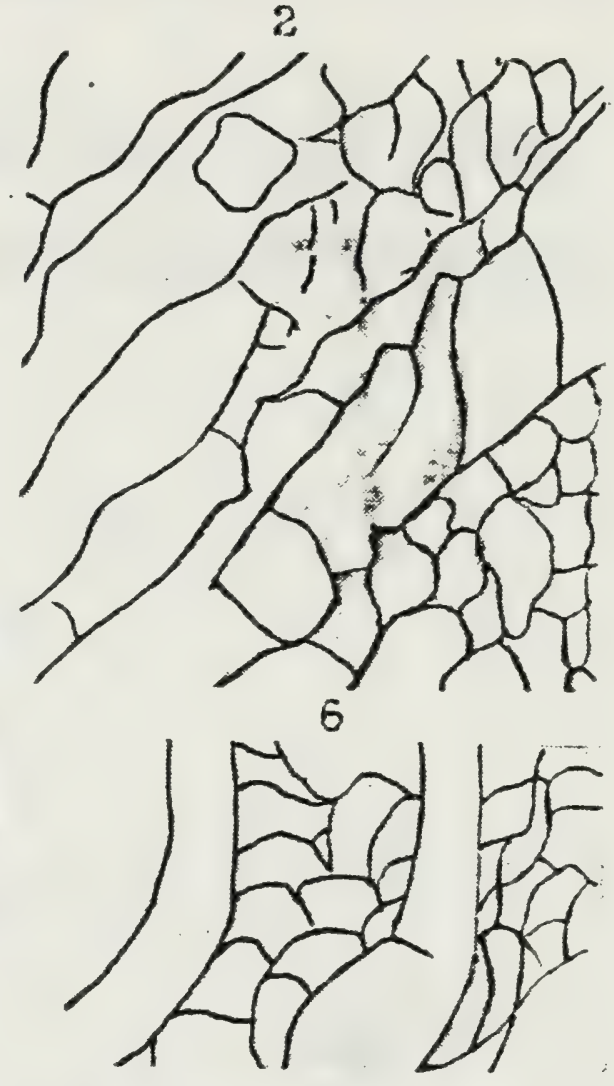

tol to

$?$

$14 e^{-\infty}$

$\because 4 l^{2}$

$a_{0}$

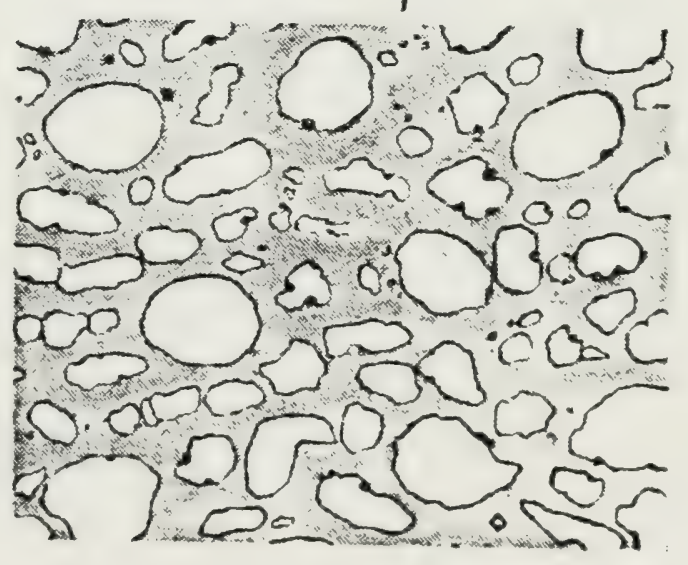





LIBRARY

RQYAL ONTARIO MUSEUM 
(196)

Ho

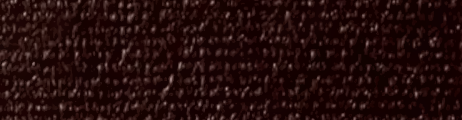

(2)

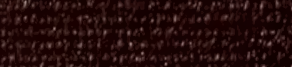

(2)

(1)

(1)

$\lim _{i \rightarrow \infty}$

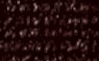

7. 6 .

6 